J. Dairy Sci. 95:2497-2504

http://dx.doi.org/10.3168/jds.2011-4830

(C) American Dairy Science Association ${ }^{\circledR}, 2012$.

\title{
Lipolysis in early lactation is associated with an increase in phosphorylation of adenosine monophosphate-activated protein kinase (AMPK)a1 in adipose tissue of dairy cows
}

\author{
L. F. Locher, ${ }^{*}$ J. Rehage, ${ }^{\star}$ N. Khraim, ${ }^{*}$ U. Meyer,† S. Dänicke,† K. Hansen,‡ and K. Huber ${ }^{1}$ \\ ${ }^{*}$ Clinic for Cattle, University of Veterinary Medicine Hannover, Foundation, 30171 Hannover, Germany \\ †Institute of Animal Nutrition, Friedrich-Loeffler-Institute (FLI) Federal Research Institute for Animal Health, 38116 Braunschweig, Germany \\ ¥Department of Physiology, University of Veterinary Medicine Hannover, Foundation, 30171 Hannover, Germany
}

\begin{abstract}
Adenosine monophosphate-activated protein kinase $(\mathrm{AMPK}) \alpha 1$ is activated in the context of triacylglycerol hydrolysis in adipose tissue in monogastric animals. This study describes AMPKa1 protein expression and the occurrence of its phosphorylated form (pAMPK $\alpha 1$ ) in different adipose tissue depots as influenced by time and postpartum diet in dairy cows. Biopsy samples were obtained from subcutaneous (SCAT) and retroperitoneal (RPAT) adipose tissues of 20 Holstein cows $21 \mathrm{~d}$ prepartum (ap) and 1 and $21 \mathrm{~d}$ postpartum (pp). After d $1 \mathrm{pp}$, cows were randomly assigned to 2 groups $(n=10)$ and fed different amounts of concentrate until the third biopsy sampling at $21 \mathrm{~d}$ pp. Protein expression of AMPK and the extent of its phosphorylation in adipose tissue were measured by semiquantitative Western blotting. Results were not influenced by postpartum feeding. Therefore, both groups were pooled and data analyzed together. Expression of AMPKo1 in SCAT showed a decrease over time, resulting in lower expression at $1 \mathrm{~d}$ pp compared with $21 \mathrm{~d}$ ap. Expression in RPAT was maintained over time. Phosphorylation increased in SCAT, showing a greater extent of phosphorylation at d $21 \mathrm{pp}$ compared with $21 \mathrm{~d}$ ap. In RPAT, this could be seen as a trend. The proportion of pAMPK $\alpha 1$ to AMPK $\alpha 1$ significantly increased over time in both tissues. In the first adipose tissue sampling (21 d ap), AMPK 1 protein expression and extent of phosphorylation were significantly higher in RPAT than in SCAT. Lipolysis in early lactation of dairy cows was associated with an increase in phosphorylation of AMPK $\alpha 1$ and ratio of pAMPK $\alpha 1$ to AMPK $\alpha 1$ in bovine adipose tissues. This indicates that AMPK $\alpha 1$ may be involved in the regulation of energy metabolism of bovine adipose tissues.
\end{abstract}

Received August 12, 2011.

Accepted December 22, 2011.

${ }^{1}$ Corresponding author: korinna.huber@tiho-hannover.de
Key words: lipolysis, adenosine monophosphateactivated protein kinase (AMPK) $\alpha 1$, subcutaneous and retroperitoneal adipose tissue, dairy cow

\section{INTRODUCTION}

Modulation of adipose tissue lipolysis in dairy cows has been examined in many excellent studies from the early 1960s until now (Opstvedt et al., 1967; Baldwin et al., 1969; Smith and McNamara, 1990; Sumner-Thomson et al., 2011). Several studies have proven that lipolysis in early lactation due to negative energy balance (NEB) of dairy cows is mainly driven by $\beta$-adrenergic stimulation via protein kinase A activation and subsequently, cyclic AMP (cAMP) formation (Jaster and Wegner, 1981; McNamara and Hillers, 1986a,b; Vernon et al., 1991; Sumner and McNamara, 2007). Cyclic AMP concentration increases in adipocytes stimulated by catecholamines. In subcutaneous adipose tissue of dairy cattle, a relationship has been shown between cAMP concentrations, lipolysis, and time around parturition (McNamara et al., 1992). Gathering pathway data comprehensively and in detail allows modeling of ruminant metabolism in order to better understand the requirements of individual animals (Hanigan et al., 2006). Therefore, the main objective of this study was to elucidate one fine-tuning process in the lipolytic pathway of different adipose tissues in the dairy cow.

\section{Modulation of Lipolysis by AMP-Activated Kinase in Monogastric Animals}

In monogastric animals, involvement of the AMPactivated kinase (AMPK) in modulation of catecholamine-driven lipolytic processes was indicated by Gauthier et al. (2008) and Omar et al. (2009), who discussed cAMP as an important factor leading to activation of AMPK in adipocytes. The AMPK phosphorylates enzymes involved in energy metabolism such as acetyl-CoA carboxylase and hormone-sensitive lipase and thereby modulates the interplay of anabolic and 
catabolic mechanisms within the cell and on a wholebody level (Rossmeisl et al., 2004). In different body tissues, including brain, AMPK is one of the key targets for hormonal signaling, leading to tissue-specific effects of nutrient signals and hormones such as leptin or adiponectin (Lim et al., 2010). Adenosine monophosphate-activated protein kinase is a heterotrimeric enzyme consisting of a catalytic $\alpha$-subunit and regulatory $\beta$ - and $\gamma$-subunits (Kahn et al., 2005; Hardie et al., 2006). In humans and rodents, the $\alpha_{1}$ and $\alpha_{2}$ subunits exist in muscle and liver with variable expression levels, whereas the $\alpha_{1}$ subunit is the predominant isoform in adipose tissue (Daval et al., 2006). On the molecular level, AMP is the metabolite that leads to AMPK activation. Adenosine monophosphate allosterically modifies AMPK and leads to phosphorylation of AMPK kinase, which in turn covalently phosphorylates AMPK at Thr 172 in the catalytic subunit. Furthermore, AMP inhibits dephosphorylation of the enzyme (Kahn et al., 2005; Daval et al., 2006). These reactions are antagonized by high concentrations of ATP. Therefore, the system more precisely reacts to the ratio of AMP to ATP rather than to cellular AMP concentrations per se (Winder and Hardie, 1999; Kahn et al., 2005). Fasting and exercise lead to activation of AMPKo1 in adipose tissue (Ruderman et al., 2003; Sponarova et al., 2005; Daval et al., 2006).

\section{Physiological Meaning of AMPK in Cattle}

In cattle, protein expression of AMPK has been investigated in the liver under conditions of reduced feed intake and mobilization of body reserves (Kuhla et al., 2009). Other groups described the distribution of AMPK mRNA in various bovine tissues and noted the special importance of the enzyme in mammary epithelial cells (McFadden and Corl, 2009). To our knowledge, data on the protein abundance of AMPKo1 in bovine adipose tissues are lacking.

\section{Hypothesis and Aim of the Study}

We hypothesized that AMPKo1 might play a role in the modulation of lipolysis in the bovine adipocyte. Phosphorylation of AMPK $\alpha 1$ might be increased in response to NEB and enhanced $\beta$-adrenergic signaling. Therefore, the aim of the present study was to investigate the changes in protein expression of AMPK $\alpha 1$ and appearance of its phosphorylated form (pAMPK $\mathbf{\alpha} \mathbf{1})$ in retroperitoneal (RPAT) and subcutaneous adipose tissue (SCAT) of dairy cows throughout the periparturient period. Furthermore, we aimed to determine the influence of postpartum energy supply on AMPK $\alpha 1$ expression and extent of phosphorylation.

\section{MATERIALS AND METHODS}

\section{Animals, Feeding, and Sample Collection}

Study design, feeding components, assessment of performance data, sample collection, and processing are described in detail in Locher et al. (2011). In brief, the study comprised 20 multiparous German Holsteins from $21 \mathrm{~d}$ prepartum (antepartum, ap) until $21 \mathrm{~d}$ postpartum (pp). Throughout the dry period, cows were fed a silage-based diet (40\% grass silage and 60\% corn silage on a DM basis). For transition feeding, starting $15 \mathrm{~d}$ ap, cows were offered concentrate in about $15 \%$ of DM of total ration. Blood samples were drawn from the jugular vein weekly throughout the study ( $21 \mathrm{~d}$ ap until $21 \mathrm{~d} \mathrm{pp}$ ) and analyzed for NEFA, BHBA, glucose, and insulin. Revised quantitative insulin sensitivity check index (RQUICKI) was calculated based as described at Holtenius and Holtenius (2007). Adipose tissue biopsies of SCAT and RPAT depots were taken on d 21 ap (19 \pm 3.5 ), 1 and $21 \mathrm{pp}$. The day after calving (after the second biopsy sampling), cows were randomly assigned to 2 different feeding groups $(\mathrm{n}=10)$ until $21 \mathrm{~d}$ pp. All diets were fed individually as a TMR and differed in concentrate:roughage ratio on a DM basis. The high concentrate group (HC) received a diet with 60:40\% and the low concentrate group (LC) with 30:70\% concentrate:roughage. The LC diet comprised $42 \%$ corn silage and $28 \%$ grass silage, whereas the $\mathrm{HC}$ diet comprised $24 \%$ corn silage and $16 \%$ grass silage. Individual feed intake and performance data were assessed daily and pooled on a weekly basis; energy balance was calculated (GfE, 2001). Performance data and results of blood metabolite analysis are given in Locher et al. (2011).

\section{Western Blot Analysis}

Preparation of Homogenates. About $50 \mathrm{mg}$ of adipose tissue powder was homogenized in $1 \mathrm{~mL}$ of prechilled lysis buffer. The homogenate was centrifuged at $1,000 \times g$ for $10 \mathrm{~min}$ at $4^{\circ} \mathrm{C}$ to remove lipids and other particulate material. The liquid phase was collected and frozen in aliquots of $100 \mu \mathrm{L}$ and stored at $-20^{\circ} \mathrm{C}$ until electrophoresis. More detailed information on homogenization process and chemicals used were published in Locher et al. (2011). Protein concentrations of the homogenates were measured according to the Bradford method (protein quantification kit, BioRad, Hercules, CA).

Electrophoresis. Homogenates were diluted in Laemmli (1970) loading buffer containing $2 \%$ mercaptoethanol and denatured by heating for $5 \mathrm{~min}$ at $95^{\circ} \mathrm{C}$ before loading $15 \mu \mathrm{g}$ per lane onto a $5 \%$ stacking gel 
and an $8.1 \%$ separation gel. In preliminary studies, 15 $\mu \mathrm{g}$ per lane was shown to be the optimum quantity for analysis. Electrophoresis was run for $30 \mathrm{~min}$ at $60 \mathrm{~V}$ and $90 \mathrm{~min}$ at $120 \mathrm{~V}$. Blotting of proteins was performed on nitrocellulose membranes with $100 \mathrm{~V}$ for $90 \mathrm{~min}$.

Detection of Proteins. Detection of specific proteins was performed after blocking the membranes in 10 and $5 \%$, respectively, fat-free milk/PBS $+0.1 \%$ Tween 20 (Roche, Basel, Switzerland), at room temperature. In preliminary studies, specificity of the AMPK $\alpha 1$ antibody for bovine AMPK $\alpha 1$ protein was validated by blocking the antibody with the respective antigenic peptide. Different concentrations of the antibodies were tested in preliminary studies to find the optimum for use in this analysis. Finally, membranes were incubated overnight at $4^{\circ} \mathrm{C}$ with primary antibodies against AMPKo1 (Bethyl, Montgomery, TX) at a concentration of 1:500 and its phosphorylated form (pAMPKo1, phosphorylated at Thr 172; Cell Signaling, Danvers, MA) at 1:1,000 and against $\beta$-actin (SigmaAldrich, St. Louis, MO) at a concentration of 1:10,000. Detection of the primary anti-pAMPKo1 antibody was performed using secondary anti-rabbit-horseradish peroxidase antibody (Cell Signaling; 1:2,000) for $1 \mathrm{~h}$ at room temperature, of anti-AMPK $\alpha 1$ using secondary anti-rabbit-horseradish peroxidase (Sigma Aldrich, $1: 50,000)$, and of anti- $\beta$-actin antibody using secondary anti-mouse antibody (Sigma-Aldrich, 1:100,000). Membranes were incubated with LumiGLO substrate (Kirkegaard \& Perry Laboratories, Gaithersburg, MD) and chemiluminescence was detected by a ChemiDoc system fitted with a digital camera (BioRad). Linear range of signal intensity development was assessed by measuring the chemiluminescence at increasing exposition times. Trace quantity of signals within the linear range was measured by densitometry using Quantity One software (BioRad). Specific band values were normalized to $\beta$-actin values as an internal standard. To adjust band values from different membranes, 2 linker samples were blotted on each membrane. The ratio of pAMPK $\alpha 1$ to AMPK $\alpha 1$ was calculated as proposed by Gauthier et al. (2011).

\section{Statistical Analysis}

Data were tested for Gaussian distribution using the Kolmogorov-Smirnov test. Because of the normal distribution of the data, parametrical statistical procedures were used. None of the measured variables were statistically different between $\mathrm{HC}$ and LC groups; therefore, data of $\mathrm{HC}$ and $\mathrm{LC}$ feeding groups were pooled and analyzed by a repeated-measures one-way ANOVA analysis (factor time) for each tissue separately. To assess differences between adipose tissue localizations at the same time of sampling, paired Student's $t$-test was used. Detailed information about the respective statistical analysis is given in each figure legend.

\section{RESULTS}

\section{Protein Expression of $\beta$-Actin}

Protein expression of $\beta$-actin in SCAT was higher $(P$ $<0.01$ ) in postpartum samples compared with that at $21 \mathrm{~d}$ ap (Figure $1 \mathrm{~A}$ ) but was maintained in RPAT over time (Figure $1 \mathrm{~B}$ ). Concentrate feeding did not affect $\beta$-actin expression.

\section{AMPKa1 Protein Expression and Extent of Phosphorylation of AMPKa1 (Thr 172) in Adipose Tissue}

Feeding different levels of concentrate pp did not influence AMPK protein expression or the extent of phosphorylation in adipose tissue depots tested in this study $[\mathrm{AMPK} \alpha 1$ (mean $\pm \mathrm{SEM})$ : LC SCAT $1.50 \pm$ 0.30 ; HC SCAT $1.02 \pm 0.18$; LC RPAT $2.25 \pm 0.41$; HC RPAT $2.10 \pm 0.47$; pAMPK 1 : LC SCAT $0.66 \pm$ 0.07 ; HC SCAT $0.85 \pm 0.29$; LC RPAT $0.97 \pm 0.13$; HC RPAT $1.30 \pm 0.30]$. Expression of AMPK 1 in SCAT showed a decrease $(P=0.003)$ over time, resulting in lower expression at $1 \mathrm{~d}$ pp compared with $21 \mathrm{~d}$ ap (Figure $2 \mathrm{~A}$ ). In contrast to this, expression in RPAT was maintained over time (Figure $2 \mathrm{~B}$ ). Phosphorylation at Thr 172 increased in SCAT $(P=0.028)$, showing a greater extent of phosphorylation at d $21 \mathrm{pp}$ compared with $21 \mathrm{~d}$ ap (Figure $2 \mathrm{C}$ ). In RPAT, this could be seen as a trend $(P=0.09$; Figure $2 \mathrm{D})$. The proportion

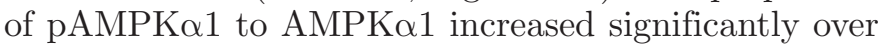
time in both tissues (Figure 3). In the first adipose tissue sampling (collected at $21 \mathrm{~d}$ ap), AMPK $\alpha 1$ protein expression and extent of phosphorylation were significantly higher in RPAT than in SCAT (Figure 4). Direct comparison between SCAT and RPAT at d 1 and 21 pp was not possible because of differences $(P<0.05)$ in $\beta$-actin protein expression between the 2 depots.

\section{DISCUSSION}

The present study investigated changes in AMPK $\alpha 1$ protein expression and the extent of its phosphorylation in adipose tissue of dairy cows throughout the periparturient period. $\beta$-Actin was used as an internal standard for normalization of results. Actin or $\beta$-actin is commonly used as an invariant standard in Western blot analysis of various tissues, including adipose tissues (Fisher et al., 2001; Arvidsson et al., 2004; Gauthier et al., 2008). Normalization of protein expression to an 


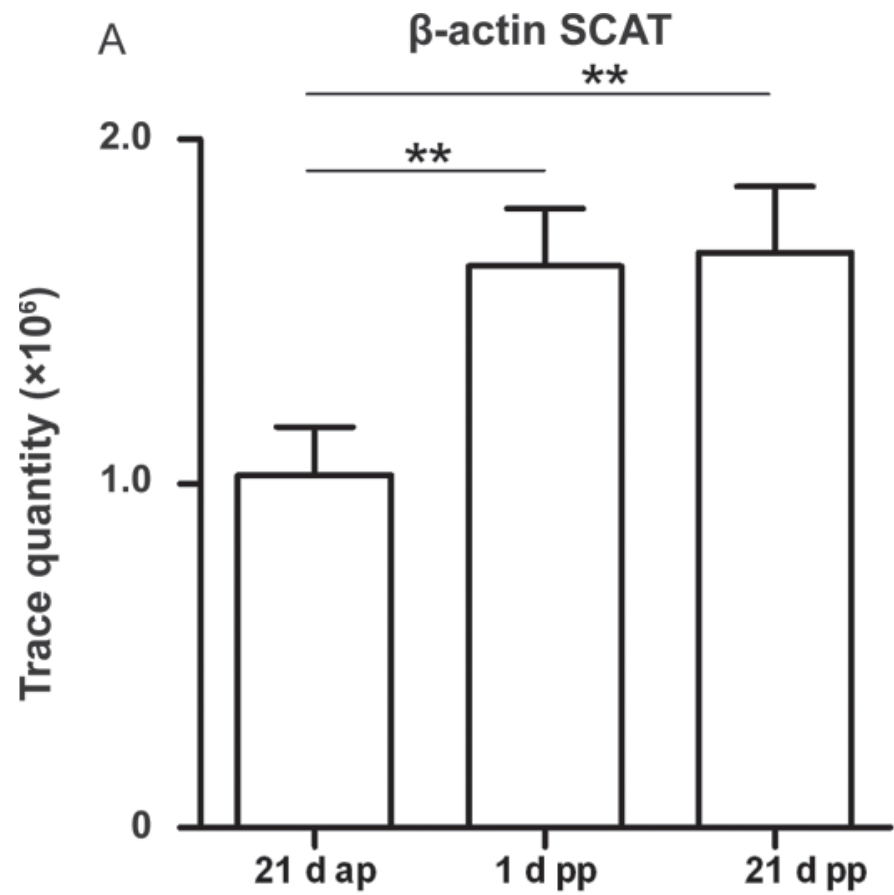

B

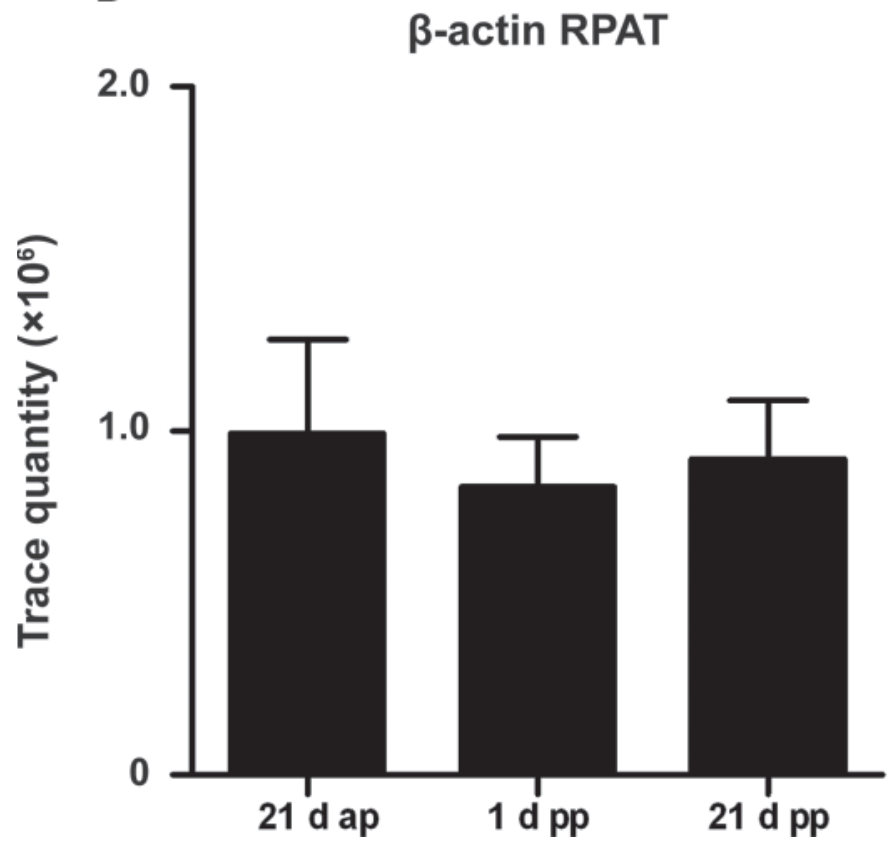

Figure 1. Expression of $\beta$-actin in subcutaneous (SCAT; A) and retroperitoneal (RPAT; B) adipose tissues at d 21 prepartum (ap) and d 1 and d 21 postpartum (pp) of German Holstein dairy cows $(n=20)$. Given are means \pm SEM; asterisks indicate significant differences ${ }^{* *} P$ $<0.01$ ) between two sampling points tested with repeated-measures one-way ANOVA and post hoc Bonferroni procedure.

internal standard requires the standard to be constitutively expressed and not influenced by the experimental factors tested. Even though it was not influenced by concentrate feeding, $\beta$-actin fully met these criteria only for RPAT in this study. In SCAT, $\beta$-actin protein expression differed between prepartum and postpartum samples. This fact has to be taken into account and critically appraised when interpreting the data of this study. In general, adipose tissue is unique in terms of having a flexible composition and dimension. This is due to the ability of subcutaneous fat cells to store and release large amounts of fat within a relatively short time span, as observed in heifers (Smith and McNamara, 1990). Confirmatively, in heifers supplemented with conjugated linoleic acid, significantly smaller adipocytes were found in subcutaneous depots from the tailhead of animals slaughtered at 105 DIM compared with animals slaughtered at 42 DIM (Akter et al., 2011). Therefore, we hypothesize that the increase in $\beta$-actin protein content despite equal amounts of SCAT tissue used for homogenization might be the result of a decrease in adipocyte size. Higher numbers of smaller fat cells compared with that in samples taken at 21 $\mathrm{d}$ ap probably resulted in a relatively higher content of $\beta$-actin protein in SCAT, rather than an absolute increase in the expression of $\beta$-actin protein. This "condensation" of subcutaneous adipose tissue might result from lipid mobilization as it occurs in the periparturient period (Smith and McNamara, 1990).

Interestingly, expression of $\beta$-actin, as well as other metabolic genes, changes at the mRNA level in the transition from nonlactating to lactating status in subcutaneous adipose tissue of dairy cows, indicating mobilization and rebuilding of adipose tissue beyond simple size changes by emptying of fat (Sumner and McNamara, 2007; Sumner-Thomson et al., 2011). Furthermore, it is not clear that relying on protein expression of a single reference protein is ideal. For real-time PCR, a combination of several genes for normalization of mRNA expression data in bovine adipose tissue has been identified (Sumner-Thomson et al., 2011). However, to our knowledge, no such systematic approach has been made in bovine adipose tissues regarding suitability of a combination of proteins to be used as internal standards for Western blotting. High plasticity of adipocytes impedes the identification of standard proteins. Relating protein expression to the DNA content of the adipose tissue might improve semiquantitative analysis of protein expression.

\section{Localization-Dependent Differences in AMPK Protein Expression}

On d 21 ap, protein expression of AMPK $\alpha 1$ and extent of phosphorylation were significantly higher in RPAT that in SCAT. This higher expression and 


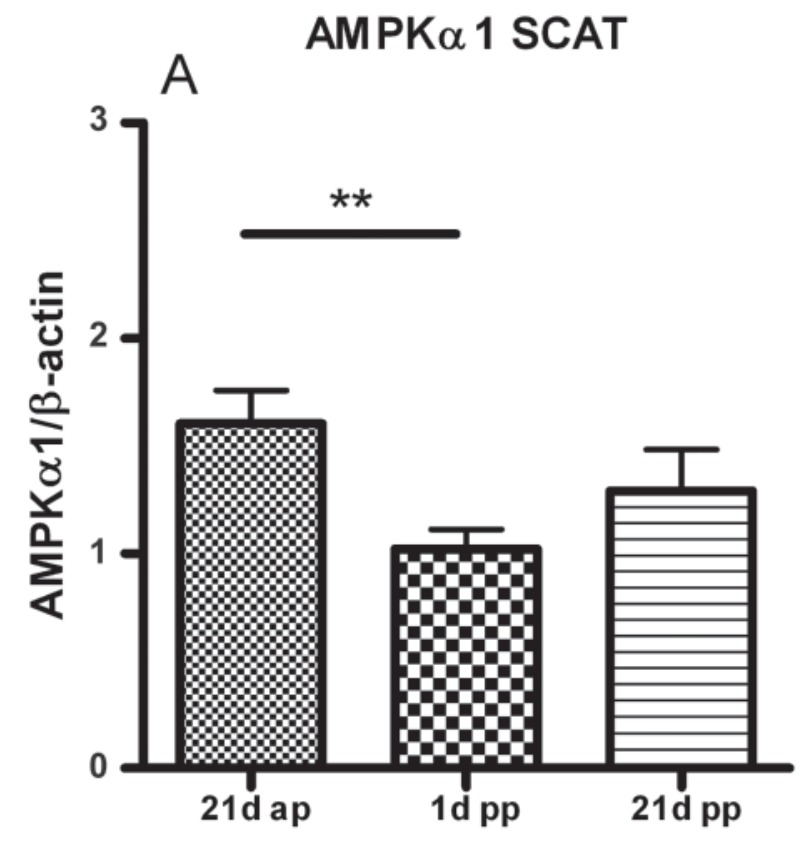

AMPK $\alpha 1$ RPAT

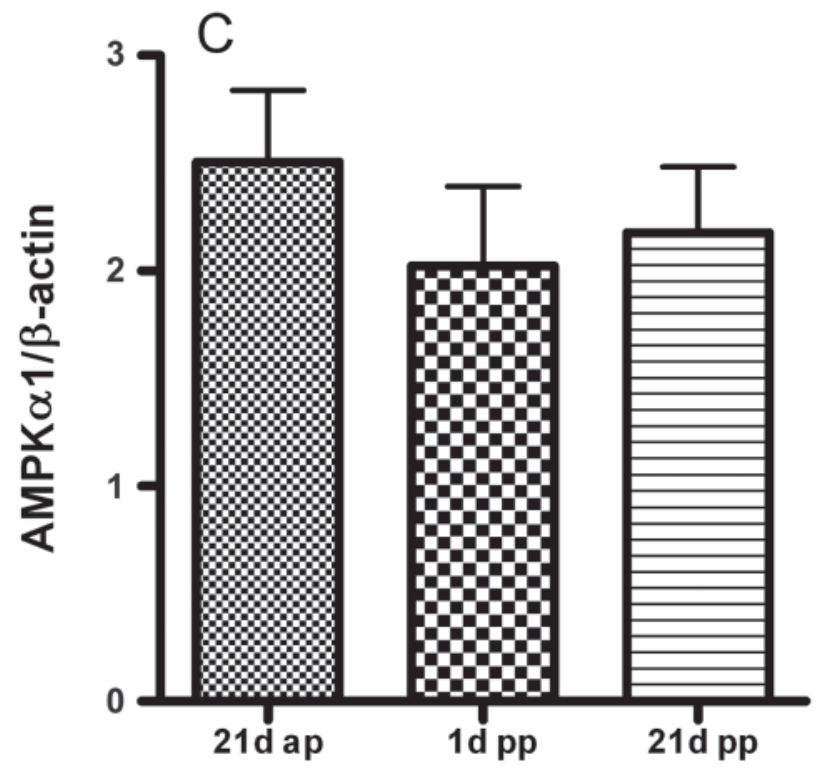

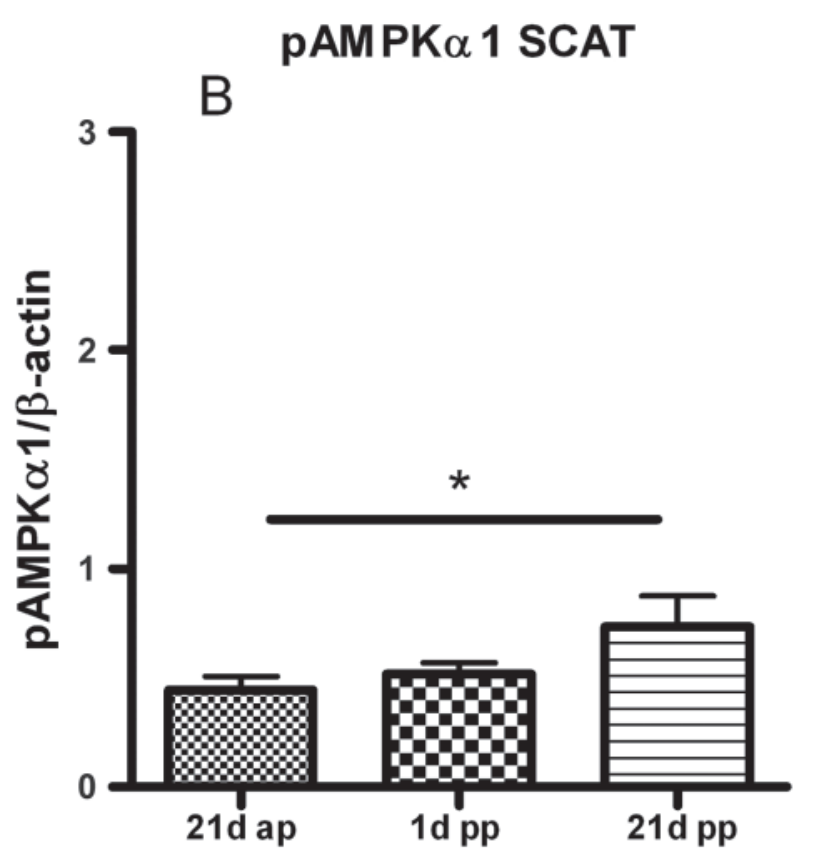

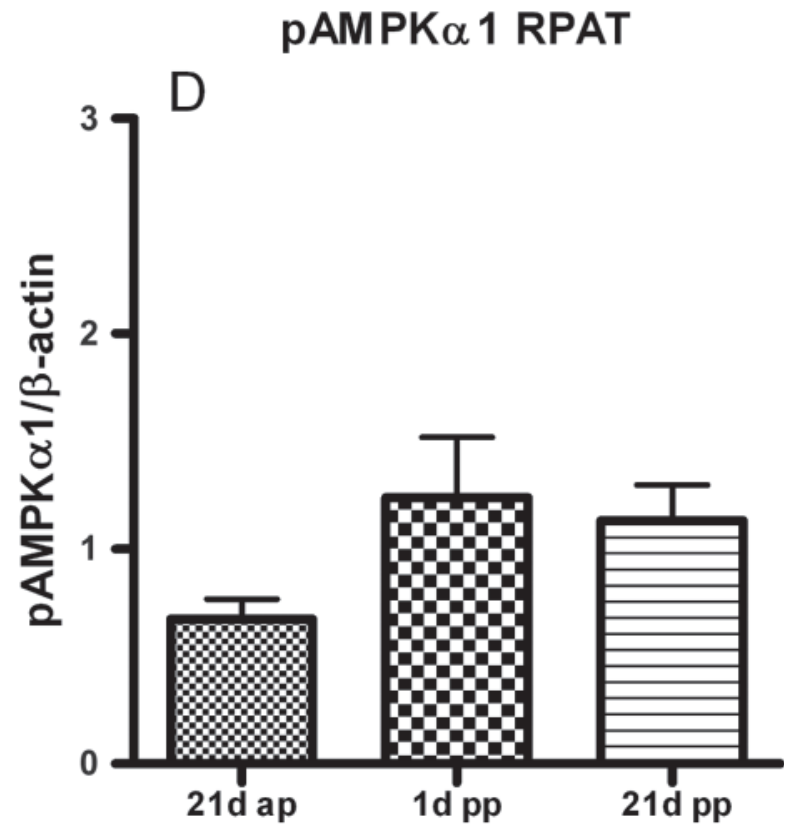

Figure 2. Total AMP-activated protein kinase (AMPK) 1 1 protein expression (A, C) and extent of phosphorylation at Thr 172 (pAMPKo1; B, D) in subcutaneous (SCAT; A, B) and retroperitoneal (RPAT; C, D) adipose tissues at d 21 prepartum (ap), d 1 and d 21 postpartum (pp) of German Holstein dairy cows $(\mathrm{n}=20)$. Given are means \pm SEM; asterisks indicate significant differences $\left(* P<0.05,{ }^{* *} P<0.01\right)$ between two sampling points tested with repeated-measures one-way ANOVA and post hoc Bonferroni procedure.

phosphorylation of AMPKo1 might indicate that RPAT has a greater capacity to respond to metabolic stimuli, as discussed previously regarding stimulation of expression of hormone-sensitive lipase and its extent of phosphorylation (Locher et al., 2011). However, the physiological importance of this remains speculative and further investigations are needed.

\section{AMPK Expression and Phosphorylation in Adipose Tissues in Connection with Lipolysis}

Expression of AMPK $\alpha 1$ in SCAT decreased significantly from prepartum to d $1 \mathrm{pp}$. Corticosteroids are thought to lower AMPK activity by decreasing the protein expression level (Kola et al., 2008). Glucocorti- 


\section{A pAMPK $\alpha 1 / A M P K \alpha 1$ SCAT}

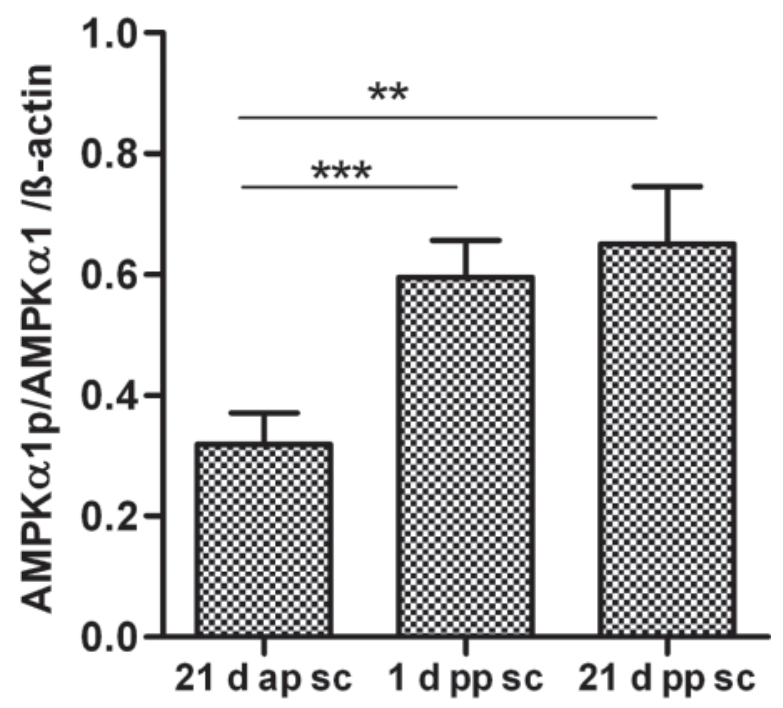

B

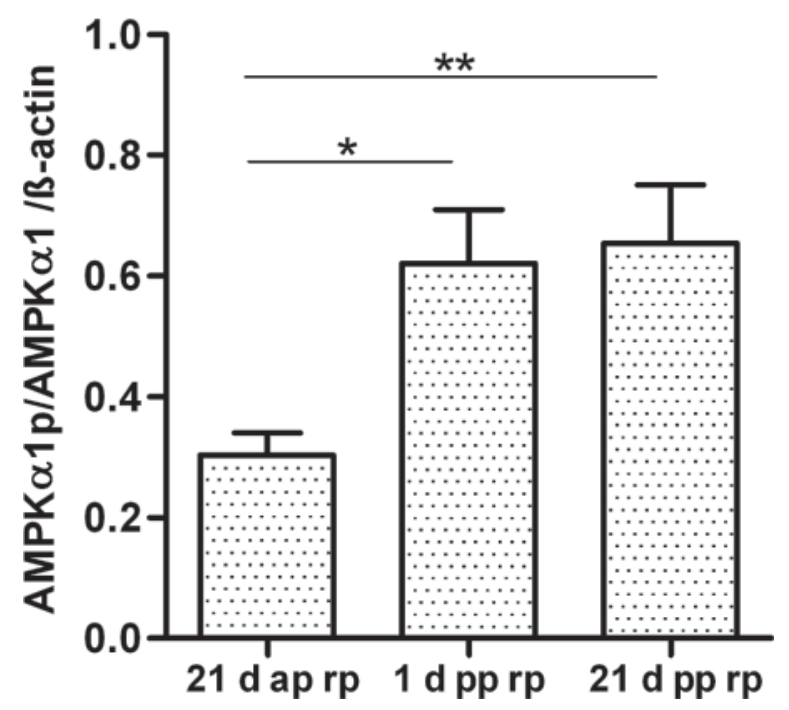

Figure 3. Ratio of Thr 172 phosphorylated AMP-activated protein

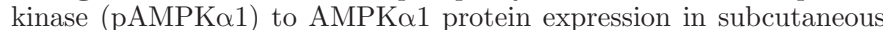
(SCAT; A) and retroperitoneal (RPAT; B) adipose tissues at d 21 prepartum (ap), d 1 and d 21 postpartum (pp) of German Holstein dairy cows $(\mathrm{n}=20)$. Given are means \pm SEM; asterisks indicate significant differences $\left(* P<0.05,{ }^{* *} P<0.01,{ }^{* * *} P<0.001\right)$ between two sampling points tested with repeated-measures one-way ANOVA and post hoc Bonferroni procedure.

coids are at high levels around parturition in dairy cows (Kindahl et al., 2004) and this endocrine signal could have contributed to the decrease in AMPK $\alpha 1$ expression. In SCAT, pAMPK $\alpha 1$ abundance was significantly higher at $21 \mathrm{~d}$ pp compared with prepartum, and the ratio of pAMPK $\alpha 1$ to AMPK 1 significantly increased in both depots. Cows in early lactation are almost all in a constant state of catabolism in adipose tissue, and increased rates of lipolysis lead to increased concentrations of NEFA and BHBA, as confirmed in this study (Locher et al., 2011).

Lipolysis in isolated 3T3L1 adipocytes has been shown to induce AMPK phosphorylation (Gauthier et al., 2008), probably due to the immediate onset of reesterification. Reesterification of NEFA is an energyconsuming process, lowering intracellular ATP and increasing intracellular AMP concentration (Brooks et al., 1982). Thus, the increase in AMPK phosphorylation in this study might be based on a similar phenomenon accompanying lipolysis. Furthermore, activated AMPK exerts direct inhibitory influence on hormone-sensitive lipase, thereby limiting diacylglycerol hydrolysis (Sullivan et al., 1994; Holm, 2003; Gaidhu et al., 2009). In this study, the increase in pAMPK $\alpha 1$ might be interpreted as an antilipolytic factor finely tuning the NEFA release from triacylglycerols. Even though in third week of lactation, energy balance was significantly more negative in the LC group $(-33.8 \pm 7.7 \mathrm{MJ} / \mathrm{d})$ than in the $\mathrm{HC}$ group $(-15.3 \pm 6.0 \mathrm{MJ} / \mathrm{d}$; Locher et al., 2011), this did not influence AMPK $\alpha 1$ phosphorylation. This might indicate that lipolysis itself, but not the degree of NEB, has an effect on AMPK $\alpha 1$ phosphorylation in this species. Another endocrine pathway may be involved in that fine-tuning system, that of

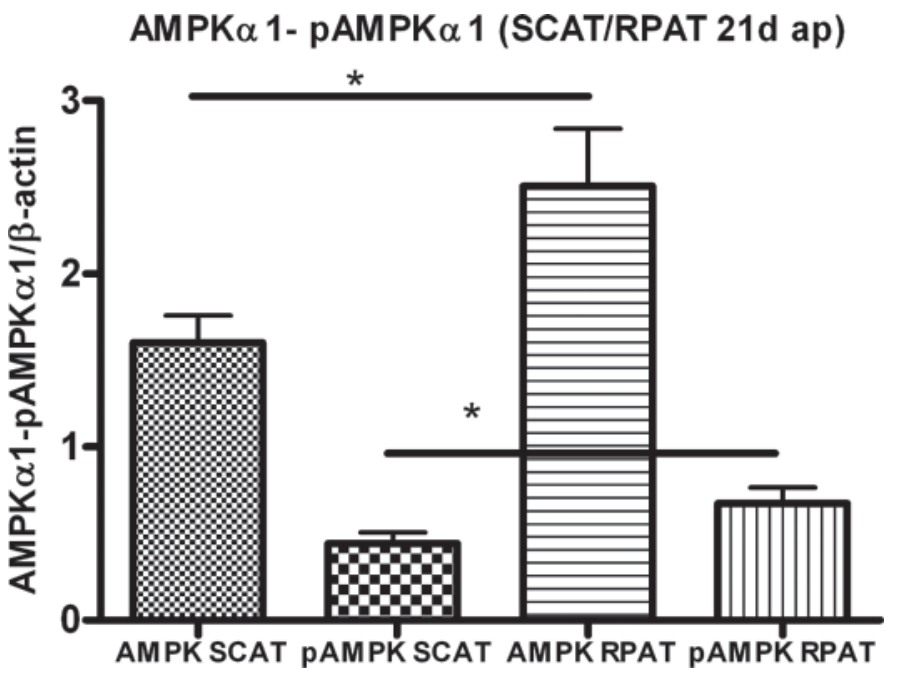

Figure 4. Total AMP-activated protein kinase (AMPK) $\alpha 1$ protein expression and extent of phosphorylation at Thr 172 (pAMPKo1) in subcutaneous (SCAT) and retroperitoneal (RPAT) adipose tissues at $\mathrm{d}$ 21 prepartum (ap) of German Holstein dairy cows $(\mathrm{n}=20)$. Given are means \pm SEM; asterisks indicate significant differences $(* P<0.05)$ between two adipose tissues tested with paired $t$-test. 
insulin. Omar et al. (2009) showed that insulin reduces $\beta$-adrenergically induced phosphorylation of AMPK. In these cows, insulin effects were reduced, as indicated by the transient decrease in total insulin concentrations and insulin sensitivity index (RQUICKI) from $0.41 \pm$ 0.01 prepartum to $0.36 \pm 0.01$ on $1 \mathrm{~d} \mathrm{pp}$, as reported by Locher et al. (2011). This might also support the increase in AMPK phosphorylation in bovine adipose tissues within the periparturient period.

\section{CONCLUSIONS}

Negative energy balance and lipolysis in early lactation of dairy cows were associated with an increase in phosphorylation of AMPK and the ratio of pAMPK $\alpha 1$ to AMPK $\alpha 1$ in bovine adipose tissues. This might be a consequence of lipolysis, independent of the feeding level and degree of NEB, and might be enhanced by reduced whole-body insulin action. Differences in protein expression and extent of phosphorylation between depots might indicate greater metabolic flexibility for the retroperitoneal adipose depot.

\section{REFERENCES}

Akter, S. H., S. Häussler, S. Dänicke, U. Müller, D. von Soosten, J. Rehage, and H. Sauerwein. 2011. Physiological and conjugated linoleic acid-induced changes of adipocyte size in different fat depots of dairy cows during early lactation. J. Dairy Sci. 94:2871-2882.

Arvidsson, E., L. Blomqvist, and M. Ryden. 2004. Depot-specific differences in perilipin mRNA but not protein expression in obesity. J. Intern. Med. 255:595-601.

Baldwin, R. L., H. J. Lin, W. Cheng, R. Cabrera, and M. Ronning. 1969. Enzyme and metabolite levels in mammary and abdominal adipose tissue of lactating dairy cows. J. Dairy Sci. 52:183-187.

Brooks, B., J. R. Arch, and E. A. Newsholme. 1982. Effects of hormones on the rate of the triacylglycerol/fatty acid substrate cycle in adipocytes and epididymal fat pads. FEBS Lett. 146:327-330.

Daval, M., F. Foufelle, and P. Ferre. 2006. Functions of AMP-activated protein kinase in adipose tissue. J. Physiol. 574:55-62.

Fisher, R. M., P. Eriksson, J. Hoffstedt, G. S. Hotamisligil, A. Thorne, M. Ryden, A. Hamsten, and P. Arner. 2001. Fatty acid binding protein expression in different adipose tissue depots from lean and obese individuals. Diabetologia 44:1268-1273.

Gaidhu, M. P., S. Fediuc, N. M. Anthony, M. So, M. Mirpourian, R. L. Perry, and R. B. Ceddia. 2009. Prolonged AICAR-induced AMP-kinase activation promotes energy dissipation in white adipocytes: Novel mechanisms integrating HSL and ATGL. J. Lipid Res. 50:704-715.

Gauthier, M. S., H. Miyoshi, S. C. Souza, J. M. Cacicedo, A. K. Saha, A. S. Greenberg, and N. B. Ruderman. 2008. AMP-activated protein kinase is activated as a consequence of lipolysis in the adipocyte: Potential mechanism and physiological relevance. J. Biol. Chem. 283:16514-16524.

Gauthier, M. S., E. L. O'Brien, S. Bigornia, M. Mott, J. M. Cacicedo, X. J. Xu, N. Gokce, C. Apovian, and N. Ruderman. 2011. Decreased AMP-activated protein kinase activity is associated with increased inflammation in visceral adipose tissue and with wholebody insulin resistance in morbidly obese humans. Biochem. Biophys. Res. Commun. 404:382-387.

GfE (Society of Nutrition Physiology). 2001. Empfehlungen zur Energie- und Nährstoffversorgung der Milchkühe und Aufzuchtrinder.
Energie- und Nährstoffbedarf landwirtschaftlicher Nutztiere. Nr. 8. DLG-Verlag. Frankfurt am Main, Germany.

Hanigan, M. D., H. G. Bateman, J. G. Fadel, and J. P. McNamara. 2006. Metabolic models of ruminant metabolism: Recent improvements and current status. J. Dairy Sci. 89(E. Suppl.):E52-E64.

Hardie, D. G., S. A. Hawley, and J. W. Scott. 2006. AMP-activated protein kinase - Development of the energy sensor concept. J. Physiol. 574:7-15.

Holm, C. 2003. Molecular mechanisms regulating hormone-sensitive lipase and lipolysis. Biochem. Soc. Trans. 31:1120-1124.

Holtenius, P., and K. Holtenius. 2007. A model to estimate insulin sensitivity in dairy cows. Acta Vet. Scand. 49:29.

Jaster, E. H., and T. N. Wegner. 1981. Beta-adrenergic receptor involvement in lipolysis of dairy cattle subcutaneous adipose tissue during dry and lactating state. J. Dairy Sci. 64:1655-1663.

Kahn, B. B., T. Alquier, D. Carling, and D. G. Hardie. 2005. AMPactivated protein kinase: Ancient energy gauge provides clues to modern understanding of metabolism. Cell Metab. 1:15-25.

Kindahl, H., B. Kornmatitsuk, and H. Gustafsson. 2004. The cow in endocrine focus before and after calving. Reprod. Domest. Anim. $39: 217-221$.

Kola, B., M. Christ-Crain, F. Lolli, G. Arnaldi, G. Giacchetti, M. Boscaro, A. B. Grossman, and M. Korbonits. 2008. Changes in adenosine 5 '-monophosphate-activated protein kinase as a mechanism of visceral obesity in Cushing's syndrome. J. Clin. Endocrinol. Metab. 93:4969-4973.

Kuhla, B., D. Albrecht, S. Kuhla, and C. C. Metges. 2009. Proteome analysis of fatty liver in feed-deprived dairy cows reveals interaction of fuel sensing, calcium, fatty acid, and glycogen metabolism. Physiol. Genomics 37:88-98.

Laemmli, U. K. 1970. Cleavage of structural proteins during the assembly of the head of bacteriophage T4. Nature 227:680-685.

Lim, C. T., B. Kola, and M. Korbonits. 2010. AMPK as a mediator of hormonal signalling. J. Mol. Endocrinol. 44:87-97.

Locher, L. F., N. Meyer, E.-M. Weber, J. Rehage, U. Meyer, S. Dänicke, and K. Huber. 2011. Hormone-sensitive lipase protein expression and extent of phosphorylation in subcutaneous and retroperitoneal adipose tissues in the periparturient dairy cow. J. Dairy Sci. 94:4514-4523.

McFadden, J. W., and B. A. Corl. 2009. Activation of AMP-activated protein kinase (AMPK) inhibits fatty acid synthesis in bovine mammary epithelial cells. Biochem. Biophys. Res. Commun. 390:388-393.

McNamara, J. P., B. Becker-Khaleel, and K. L. Parmley. 1992. Quantitative relationships between cyclic adenosine- $3^{\prime} 5^{\prime}$-monophosphate and lipolysis in adipose tissue during the periparturient period. J. Dairy Sci. 75:1901-1913.

McNamara, J. P., and J. K. Hiller. 1986a. Regulation of bovine adipose tissue metabolism during lactation. 1. Lipid synthesis in response to increased milk production and decreased energy intake. J. Dairy Sci. 69:3032-3041.

McNamara, J. P., and J. K. Hillers. 1986b. Regulation of bovine adipose tissue metabolism during lactation. 2. Lipolysis response to milk production and energy intake. J. Dairy Sci. 69:3042-3050.

Omar, B., E. Zmuda-Trzebiatowska, V. Manganiello, O. Goransson, and E. Degermann. 2009. Regulation of AMP-activated protein kinase by cAMP in adipocytes: Roles for phosphodiesterase, protein kinase B, protein kinase A, Epac and lipolysis. Cell. Signal. $21: 760-766$.

Opstvedt, J., R. L. Baldwin, and M. Ronning. 1967. Effect of diet upon activities of several enzymes in abdominal adipose and mammary tissues in the lactating dairy cow. J. Dairy Sci. 50:108-109.

Rossmeisl, M., P. Flachs, P. Brauner, J. Sponarova, O. Matejkova, T. Prazak, J. Ruzickova, K. Bardova, O. Kuda, and J. Kopecky. 2004. Role of energy charge and AMP-activated protein kinase in adipocytes in the control of body fat stores. Int. J. Obes. Relat. Metab. Disord. 28(Suppl. 4):S38-S44.

Ruderman, N. B., H. Park, V. K. Kaushik, D. Dean, S. Constant, M. Prentki, and A. K. Saha. 2003. AMPK as a metabolic switch in rat muscle, liver and adipose tissue after exercise. Acta Physiol. Scand. 178:435-442. 
Smith, T. R., and J. P. McNamara. 1990. Regulation of bovine adipose tissue metabolism during lactation. 6. Cellularity and hormonesensitive lipase activity as affected by genetic merit and energy intake. J. Dairy Sci. 73:772-783.

Sponarova, J., K. J. Mustard, O. Horakova, P. Flachs, M. Rossmeisl, P. Brauner, K. Bardova, M. Thomason-Hughes, R. Braunerova, P. Janovska, D. G. Hardie, and J. Kopecky. 2005. Involvement of AMP-activated protein kinase in fat depot-specific metabolic changes during starvation. FEBS Lett. 579:6105-6110.

Sullivan, J. E., K. J. Brocklehurst, A. E. Marley, F. Carey, D. Carling, and R. K. Beri. 1994. Inhibition of lipolysis and lipogenesis in isolated rat adipocytes with AICAR, a cell-permeable activator of AMP-activated protein kinase. FEBS Lett. 353:33-36.
Sumner, J. M., and J. P. McNamara. 2007. Expression of lipolytic genes in the adipose tissue of pregnant and lactating Holstein dairy cattle. J. Dairy Sci. 90:5237-5246.

Sumner-Thomson, J. M., J. L. Vierck, and J. P. McNamara. 2011. Differential expression of genes in adipose tissue of first-lactation dairy cattle. J. Dairy Sci. 94:361-369.

Vernon, R. G., E. Finley, and P. W. Watt. 1991. Adenosine and the control of adrenergic regulation of adipose tissue lipolysis during lactation. J. Dairy Sci. 74:695-705.

Winder, W. W., and D. G. Hardie. 1999. AMP-activated protein kinase, a metabolic master switch: Possible roles in type 2 diabetes. Am. J. Physiol. 277:E1-E10. 